\title{
A Law and Economics Approach to Norms in Transnational Commercial Transactions: Incorporation and Internalisation
}

\author{
Bo Yuan*
}

\begin{abstract}
In today's global economy, a noticeable trend is that the traditional state-law-centred legal framework is increasingly challenged by self-regulatory private orders. Commercial norms, commercial arbitration and social sanctions at the international level have become important alternatives to national laws, national courts and legal sanctions at the national level. Consisting of transnational commercial norms, both codified and uncodified, and legal norms, both national and international, a plural regime for the governance of transnational commercial transactions has emerged and developed in the past few decades. This article explores the interaction between various kinds of norms in this regime, identifies the effects of this interaction on the governance of transnational commercial transactions and shows the challenges to this interaction at the current stage. The central argument of this article is that the interaction between social and legal norms, namely incorporation and internalisation, and the three effects derived from incorporation and internalisation, namely systematisation, harmonisation and compliance enhancement, are evident at both the national and international levels. In particular, the emergence of codified transnational commercial norms that are positioned in the middle of the continuum between national legal norms and uncodified transnational commercial norms has brought changes to the interaction within the international dimension. Although the development of codified transnational commercial norms faces several challenges at the moment, it can be expected that these norms will play an increasingly important role in the future governance of transnational commercial transactions.
\end{abstract}

Keywords: Incorporation and internalisation, transnational commercial transactions, transnational commercial norms

\section{Introduction}

In today's global economy, transnational commercial norms (social norms in transnational commercial transactions) play an increasingly important role in transna-

* Bo Yuan is a Ph.D. candidate at the Erasmus University Rotterdam, Department of Law and Economics. tional commercial transactions. ${ }^{1}$ This trend has been identified and discussed in a vast body of literature, especially on the topic of the lex mercatoria (the Law Merchant). ${ }^{2}$ Transnational commercial norms, such as trade usages and commercial customs, are frequently referred to by arbitrators when interpreting legal provisions and contractual terms. ${ }^{3}$ It is also found that transnational commercial norms, for example the UNIDROIT Principles of International Commercial Contracts (UNIDROIT Principles), are directly designated by disputing parties as the governing rules for deciding transnational commercial disputes. ${ }^{4}$ As an important alternative to national legal norms, transnational commercial norms have become an indispensable part of the governance of transnational commercial transactions. ${ }^{5}$

The development of transnational commercial norms is closely connected with the principles of party autonomy and freedom of contract. ${ }^{6}$ The promotion of these two principles by modern states provides transnational merchants with considerable freedom in designing their contracts according to their own specific needs and

1. The term 'transnational commercial norms' is used in this article to refer to social norms generated from transnational mercantile practice. Strictly speaking, 'transnational commercial norms' and lex mercatoria are not interchangeable terms, though their meaning and scope are similar to each other. For terminology and the connection between these two terms, see A.F.M. Maniruzzaman, 'The Lex Mercatoria and International Contracts: A Challenge for International Commercial Arbitration?', 14 American University International Law Review 657, at 660-70 (1999).

2. For the debate on lex mercatoria, see generally K.P. Berger, The Creeping Codification of the New Lex Mercatoria (2010). See also R. Michaels, 'The True Lex Mercatoria: Law beyond the State', 14 Indiana Journal of Global Legal Studies 447 (2007). M.L. Musttill, 'The New Lex Mercatoria: The First Twenty-Five Years', 4 Arbitration International 86 (1988).

3. C.R. Drahozal, 'Commercial Norms, Commercial Codes, and International Commercial Arbitration', 33 Vanderbilt Journal of Transnational Law 79, at 133 (2000). The sources of transnational commercial norms are further discussed in Section 4.3.

4. K.P. Berger, 'International Arbitral Practice and the UNIDROIT Principles of International Commercial Contracts', 46 The American Journal of Comparative Law 129, at 143-49 (1998); Drahozal (2000), above n. 3 , at 128.

5. The term 'governance' is used in law and economics literature to refer to the regulatory control over transnational commercial transactions in a general sense. See e.g. G.P. Calliess and M. Renner, 'Between Law and Social Norms: The Evolution of Global Governance', 22 Ratio Juris 260 (2009); A.S. Sweet, 'The New Lex Mercatoria and Transnational Governance', 13 Journal of European Public Policy 627 (2006).

6. B. Cremades and S. Plehn, 'The New Lex Mercatoria and the Harmonization of the Laws of the International Commercial Transactions', 2 Boston University International Law Review 317, at 328 (1984). 
selecting their preferred governing laws and dispute resolution mechanisms accordingly. The parties can, one the one hand, rely on public mechanisms and resolve contract disputes in national courts on the basis of national legal norms, while, on the other hand, they can also use private mechanisms and settle contract disputes in international arbitration institutions on the basis of transnational commercial norms. ${ }^{7}$ Moreover, the two mechanisms are not mutually exclusive, but can be jointly employed by the parties in a mixed manner. Simply stated, private and public mechanisms are not only competing but also complementing with each other in the fields of norm production, dispute resolution and contract enforcement, which create a 'hybrid' legal regime for governing transnational commercial transactions. ${ }^{8}$ In this context, it is necessary to reconsider the interaction between the norms in this regime and their roles in the governance of transnational commercial transactions.

This article explores the interaction between transnational commercial norms, both codified and uncodified, and legal norms, both national and international, in the field of transnational commercial transactions, ${ }^{9}$ and aims to answer the following question: how do transnational commercial norms and legal norms interact with each other, and how can the interaction affect the governance of transnational commercial transactions? ${ }^{10}$ To approach this issue, the general strategy of this article is to first develop a theoretical framework based on the law and economics theories regarding the creation and enforce-

7. G.P. Calliess, W. Konradi, H. Nieswandt, F.P. Sosa \& T. Dietz, ‘Transformations of Commercial Law: New Forms of Legal Certainty for Globalized Exchange Processes?', in A. Hurrelmann, S. Leibfried, K. Martens \& P. Mayer (eds.), Transforming the Golden Age Nation State (2007) 83, at 83-108.

8. G. Teubner, 'Hybrid Laws: Constitutionalizing Private Governance Networks', in R. Kagan, M. Krygier \& K. Winston (eds.), Legality and Community: On the Intellectual Legacy of Philip Selznick (2002) 311, at 311-31. See also G.P. Calliess, 'The Making of Transnational Contract Law', 14 Indiana Journal of Global Legal Studies 469, at 469-83 (2007); Sweet, above n. 5, at 627-46; P. Zumbansen, 'Piercing the Legal Veil: Commercial Arbitration and Transnational Law', 8 European Law Journal 400, at 400-32 (2002); F.K. Juenger, 'The Lex Mercatoria and Private International Law', 60 Louisiana Law Review 1133, at 1133-1150 (2000)

9. The categorisation of norms in transnational commercial transactions is further discussed in Section 3.3.

10. Apart from the focus of this article (the effects of the interaction between the norms in transnational commercial transactions), law and economics approaches are also used to analyse other important issues regarding this interaction. These issues cover norm evolution, norm competition and the pros and cons of harmonisation. For norm evolution, see e.g. J.S. Kraus, 'Legal Design and the Evolution of Commercial Norms', 26 The Journal of Legal Studies 377 (1997); B.L. Benson, 'The Spontaneous Evolution of Commercial Law', 55 Southern Economic Journal 644 (1989). For norm competition, see e.g. S. Vogenauer, 'Regulatory Competition through Choice of Contract Law and Choice of Forum in Europe: Theory and Evidence', 1 European Review of Private Law 13 (2013); G. Ruhl, 'The Choice of Law Framework for Efficient Regulatory Competition in Contract Law', in H. Eidenmuller (ed.), Regulatory Competition in Contract Law and Dispute Resolution (2013) 287. For the pros and cons of harmonisation, see e.g. F. Gomez, 'The Harmonization of Contract Law through European Rules: A Law and Economics Perspective', 4 European Review of Contract Law 89 (2008); G. Wagner, 'The Economics of Harmonisation: The Case of Contract Law', 3 ERA Forum 77 (2002). ment of social and legal norms and their interaction at the national level, and then apply these theories to the international level to analyse the interaction between transnational commercial norms and legal norms in the context of transnational commercial transactions. ${ }^{11}$

Following the Introduction, Part 2 illustrates how social and legal norms are generated and enforced, how social and legal norms interact with each other through incorporation and internalisation, and how the three effects derived from incorporation and internalisation, namely systematisation, harmonisation, and compliance enhancement, can reduce the cost of norm usage, enhance norm enforcement and unify individuals' different opinions. Part 3 reviews how different kinds of norms in transnational commercial transactions emerged and developed in history, how they form a continuum between uncodified transnational commercial norms and national legal norms and how codified transnational commercial norms are positioned in this continuum. Part 4 applies the theories generalised in Part 2 to the context of transnational mercantile practice, and studies the interaction between the norms in transnational commercial transactions identified in Part 3. Particularly, Part 4 illustrates the important role of codified transnational commercial norms in this interaction and the challenges this interaction is facing at the current stage. The article then concludes with a few thoughts on the future development of this interaction and the role of codified transnational commercial norms in the future governance of transnational commercial transactions.

\section{Social and Legal Norms: A Law and Economics Perspective}

\subsection{Creation and Enforcement of Social and Legal Norms: Private and Public Mechanisms}

\subsubsection{Social Norms and Private Mechanisms}

The creation of social norms can be understood as a process of gradual emergence of consensus between

11. To the author's knowledge, there is still no comprehensive theoretical framework that is specifically designed to illustrate the interaction between the norms in transnational commercial transactions. Hence, this article adopts an alternative approach that starts with a general theoretical framework developed on the basis of the interaction between social and legal norms at the national level, and then applies the general theories at the national level in the context of transnational commercial transactions. But some related theoretical discussion is helpful for understanding the governance of transnational commercial transactions. See generally G. Cunieberti, 'Three Theories of Lex Mercatoria', 52 Columbia Journal of Transnational Law 369, at 369-434 (2014); Vogenauer, above n. 10, at 13-78; Ruhl, above n. 10, at 287-303; M.A. Petsche, 'International Commercial Arbitration and the Transformation of the Conflict of Laws Theory', 18 Michigan State Journal of International Law 454, at 454-93 (2010). 
members of a community. ${ }^{12}$ Individuals naturally have certain judgements, normally in the form of approval or disapproval, upon certain behaviour and may react to the behaviour by rewarding or punishing the actor. ${ }^{13}$ These judgements and reactions reflect the general attitude of community members towards the behaviour. When the majority of community members reach a consensus on whether certain behaviour should be encouraged or prohibited, social norms are then generated. ${ }^{14}$ In brief, social norms can be understood as rules of behaviour. They inform community members whether certain behaviour is appropriate or not in a community. ${ }^{15}$

From a law and economics perspective, individuals follow social norms in light of different incentives. These incentives can be roughly divided into two categories: mental or material. ${ }^{16}$ Some social norms are normative and supported mainly by mental incentives. These social norms are derived from the collective 'normative attitudes' of community members. ${ }^{17}$ Some attitudes such as the opposition to murder, rape or child abandonment are deeply held by most people, while other opinions such as an aversion to impoliteness, unpunctuality and unruliness are expressed in a relatively mild manner. Be they strong or weak, individuals follow these kinds of social norms because conforming to these social norms increases their mental utility or violating these social norms reduces their mental utility. For example, they may feel guilty or ashamed or be blamed by others for not fulfilling these obligations. Individuals may even follow standards that go beyond the basic behaviour requirements to feel proud or to obtain praise from others. In general, guilt, pride, esteem, disapproval and shame are the main mental incentives that motivate individuals to follow social norms in light of mental incentives. ${ }^{18}$

Individuals may also comply with social norms for the sake of material utility. They do so not because they normatively deem certain behaviour appropriate or not, but because following these social norms can bring them material gains or avoid unnecessary losses. There are three important economic models that explain why social norms are followed by individuals in light of material incentives, namely the coordination game model, the repeated games model and the signalling model. ${ }^{19}$ The coordination game model indicates how individuals can avoid unnecessary losses by following coordination norms. For example, in the classic car-driving example, drivers follow the same traffic rule of driving on left or right to avoid car crashes. ${ }^{20}$ This model is also useful for explaining why merchants tend to follow unified technical standards in trade. The repeated games model shows that individuals are inclined to cooperate with each other rather than cheat in a long-term relationship, as the one-off gain from cheating is normally outweighed by potential future gains from following cooperative norms in repeated games. ${ }^{21}$ By the same token, merchants are motivated to comply with contractual terms instead of violating them to preserve future cooperation opportunities with their partners in repeated transactions. Accordingly, in the signalling model, individuals use signalling norms to inform others that they are longtime 'cooperators' instead of one-round 'cheaters', as the cost of following signalling norms outweighs the
12. R.A. Posner and E.B. Rasmusen, 'Creating and Enforcing Norms, with Special Reference to Sanctions', 19 International Review of Law and Economics 369, at 2 (1999). As social norms may vary from community to community, this article uses the term 'community members' to emphasise that social norms are collectively created and enforced by individuals in a certain community. The size or the scope of communities also varies. It can be as small as a family, a neighbourhood or a club. It can also be as large as a city, a country or the whole human society.

13. E.A. Posner, 'Law, Economics, and Inefficient Norms', 144 University of Pennsylvania Law Review 1697, at 1699 (1996). Sometimes, individuals may also react to their own behaviour. For example, a person who thinks his or her own behaviour is inappropriate, may feel guilty or ashamed. This issue is further discussed in the following paragraphs of this section.

14. R.D. Cooter, 'Structural Adjudication and the New Law Merchant: A Model of Decentralized Law', 14 International Review of Law and Economics 215, at 224 (1994).

15. Many law and economics scholars use 'norms' to refer to social norms and 'law' for legal norms. But there is also some law and economics literature that explicitly uses the term 'social norms'. See e.g. E.A. Posner, 'The Signaling Model of Social Norms: Further Thoughts', 36 University of Richmond Law Review 465 (2002); E.A. Posner, 'Standards, Rules, and Social Norms', 21 Harvard Journal of Law \& Public Policy 101, at 101-17 (1997).

16. In McAdams and Rasmusen's discussion, these two kinds of social norms are termed 'norms' and 'conventions'. R.H. McAdams and E.B. Rasmusen, 'Norms and the Law', in M. Polinsky and S. Shavell (eds.), Handbook of Law and Economics (2007) 1537, at 1577-1578.

17. Posner and Rasmusen, above n. 12, at 372-76.
18. McAdams and Rasmusen, above n. 16, at 1579-1580.

19. There are also other theoretical models applicable to social norms, the cascade model for example. See generally S. Bikhchandani, D. Hirshleifer \& I. Welch, 'A Theory of Fads, Fashion, Custom, and Cultural Change as Informational Cascades', 100 Journal of Political Economy 992 (1992). But since other theoretical models are not closely connected to the discussion in this article, they are not discussed in detail.

20. If there were no traffic rules regulating which side to drive on, drivers would need to slow down and even communicate with each other to make sure they both drive on the left or right to avoid car crashes. But it would be too time-consuming if drivers needed to agree on a temporary solution for which side to drive on whenever they met other cars on the road. Thus, it is necessary for drivers to follow a unified traffic rule that prescribes that all drivers should drive on the left or right. This kind of traffic rules are typical coordination norms. Individuals are motivated to follow coordination norms to avoid unnecessary material losses and save the time for seeking a temporary solution. See Posner (1997), above n. 15, at 110

21. In repeated games, generally speaking, one participant should cooperate with the other participant unless the other participant cheated in the previous round. The reason why the tit-for-tat strategy is the best option in repeated games can be explained by game theory. A short explanation is that if one participant tries to cheat in the game, he or she may lose the opportunity of further cooperation and thus lose potential future gains. This is especially true when there are other candidates who can replace the participant who cheated in the game. Cooter (1994), above n. 14, at 218-20. Posner (1997), above n. 15, at 108. 
gains that a cheater can make from cheating in oneround transactions. ${ }^{22}$

\subsubsection{Legal Norms and Public Mechanisms}

Similarly to social norms, legal norms also serve to guide individuals' behaviour. ${ }^{23}$ But, different from social norms, which are mainly created and enforced by community members themselves, ${ }^{24}$ the creation and enforcement of legal norms are mainly dependent on legislative, administrative and judicial organs. ${ }^{25}$ In civil law tradition, legal norms are established by legislators in the form of statutory laws, while judges in common law tradition produce legal norms through their decisions, the aggregation of which then gradually becomes judicial precedents and common law doctrines. ${ }^{26} \mathrm{By}$ the same token, one major, if not the most important, incentive for individuals to follow legal norms is the fear of legal sanctions imposed by state organs.

As two different kinds of norms relying on private or public mechanisms, social and legal norms have different strengths and drawbacks. On the one hand, social norms are relatively general, ambiguous and flexible. They rarely provide clear and definite guidance to individuals on behaviour requirements and potential sanctions. ${ }^{27}$ Compared with social norms, legal norms are normally more precise, explicit and coercive. ${ }^{28}$ On the other hand, the creation and enforcement of legal norms generally incur more cost than social norms. The establishment and maintenance of public institutions and legislative, administrative and judicial activities are all resource-consuming. Compared with legal norms, the creation and enforcement of social norms are spontaneously conducted by community members themselves

22. In real life, it is difficult for merchants to find enough information to ascertain whether a potential trader is a cooperator or a cheater. Signalling behaviour is a common solution to this problem. Specifically, signalling behaviour is normally costly and outweighs the short-run gains that a cheater can make from cheating in one round transaction. Thus, only cooperators who aim at long-term gains are willing to take costly signalling actions. In other words, signalling behaviour can be regarded as a signal that informs other merchants of the willingness of the actor to establish long-term cooperation. For example, traditional diamond merchants in the United States must draft their contracts with a particular style of contracting, which consumed considerable time and money to learn. One needed to bear this cost to send signals to other diamond merchants that he or she would be a credible partner in the diamond trade. See E.A. Posner, 'Symbols, Signals, and Social Norms in Politics and the Law', 27 The Journal of Legal Studies 765, at 768 (1998); Posner (1997), above n. 15, at 109-10.

23. R.A. Posner, 'Social Norms and the Law: A Economic Approach', 87 The American Economic Review 365, at 365-69 (1997).

24. Posner and Rasmusen, above n. 12, at 369-70.

25. Ibid. The creation and enforcement of legal norms is further elaborated in Section 2.2.

26. R. Pound, 'Common Law and Legislation', 21 Harvard Law Review 383, at 404-6 (1908).

27. For example, how quiet is quiet enough in the library? The answer may vary from person to person. Even if one person speaks really loudly so that all the people in the library agree to punish him or her, what should be the sanctions? No definitive answers can be given. See Posner and 28. Ibid. and are thus generally less costly. ${ }^{29}$ But, as shown in the following section, the creation and enforcement of social and legal norms are closely connected with each other. Many legal norms have their roots in social norms, while some social norms are also derived from legal norms. ${ }^{30}$ More importantly, the interaction between social and legal norms can diminish their differences and creates a common basis for them to complement each other in guiding individuals' behaviour and maintaining social order.

\subsection{Interaction between Social and Legal Norms: Incorporation and Internalisation}

\subsubsection{Incorporation}

Social norms can turn into legal norms through the process of incorporation. The origins of many legal norms in statutory laws can be found in social norms. It is common to find that legislators study existing social norms and selectively incorporate them into national laws. ${ }^{31}$ Similarly to legal norms in statutory laws, many legal norms in common law doctrines are also the products of the incorporation process. In common law tradition, judges follow established common law doctrines to decide cases. When there are no applicable pre-existing common law doctrines, judges then need to rely on their 'sense of justice' to reach a decision. ${ }^{32}$ In doing so, they tend to observe social practice and discover existing social norms as the basis of decisions. These decisions that are essentially created on the basis of social practice and social norms then gradually turn into judicial precedents and common law doctrines. From this perspective, legal norms in common law doctrines are actually incorporated social norms derived from judges' intellectual refinement. ${ }^{33}$

The incorporation process reflects a bottom-up approach to law-making, through which selected social norms become more coercive and systematic. Specifically, when selected social norms are incorporated into

29. Cooter summarises these differences between social and legal norms as their 'complementary strengths' for maintaining social order. Some kinds of behaviour, such as keeping quiet in the library, following a queue or cleaning tables after a meal, are more suitable for social norms to govern, for it would be too costly for legal norms to govern them. Correspondingly, some kinds of behaviour, such as murder, robbery and theft, should be governed mainly by legal norms, for they need to be subject to strict control. R.D. Cooter, 'Three Effects of Social Norms on Law: Expression, Deterrence, and Internalization', 79 Oregon Law Review 1, at 21-22 (2000).

30. It should be noted that the terms 'incorporation' and 'internalization' are not necessarily used to describe the interaction between social and legal norms in the literature. See e.g. K. Rittich, 'The Future of Law and Development: Second Generation Reforms and the Incorporation of the Social', 26 Michigan Journal of International Law 199 (2004); A. Etzioni, 'Social Norms: Internalization, Persuasion, and History', 34 Law \& Society Review 157 (2000).

31. R. Michaels, 'The Re-State-Ment of Non-State Law: The State, Choice of Law, and the Challenge from Global Legal Pluralism', 51 The Wayne Law Review 1209, at 1232 (2005). R.D. Cooter, 'Decentralized Law for a Complex Economy: The Structural Approach to Adjudicating the New Law Merchant', 144 University of Pennsylvania Law Review 1643, at 1651 (1996).

32. Posner (1996), above n. 13, at 1699.

33. Cooter (1996), above n. 31, at 1648. 
legal norms, they also gain the legal authority and coercion from state power. After incorporation, individuals follow these norms not only to avoid social sanctions but also for fear of state violence. ${ }^{34}$ Moreover, individuals need to spend time and energy in recognising norms before using them. Such cost is reduced when originally vague, unwritten and fragmented social norms that are relatively difficult to find and learn turn into precise, written and coherent legal norms that can be readily used. In brief, the systematisation effect makes it easier and less costly for individuals to use these incorporated norms.

\subsubsection{Internalisation}

Another form of the interaction between social and legal norms is internalisation. Not all legal norms are created on the basis of existing social norms. There are several reasons for states to directly establish new legal norms through legislation. First, from a law and economics perspective, social norms are likely to be 'undercreated and underenforced' as no one can find direct interest from creating and enforcing social norms. ${ }^{35}$ Accordingly, vacancies that are not covered by social norms need to be fulfilled by legal norms. Second, the generation of social norms is normally a gradual process that may take years to realise. It is possible that social norms cannot timely respond to new developments in society. Third, some social norms, duelling and lynch for example, are 'bad' norms that need to be changed. ${ }^{36}$ Fourth, social norms are not necessarily efficient or optimal. ${ }^{37}$ Last, states may also establish new legal norms based on policy goals.

These newly established legal norms normally have no solid root in social norms. But they can be gradually internalised by individuals and turn into social norms over time. ${ }^{38}$ To illustrate, assume that there are no wellaccepted social norms against smoking in public places. Some individuals may deem smoking in public places as misbehaviour, while others may consider the issue as merely a personal choice. A government may directly issue a regulation to prohibit smoking in public places for the concern of public health. Initially, some individuals may just stop smoking in public places because of the threat of legal punishment, though they still insist that whether or not to smoke in public places is a personal choice. But the compulsory compliance with the new legal norm, as well as the increasing social pressure from others, may gradually destabilise the insistence. Over time, there will be more and more individuals accepting the new rule that smoking is not appropriate in public places. Consequently, this new legal norm will be ultimately internalised by the majority and turn into a social norm. Even if this rule is not enforced by state officials, individuals will still follow this rule to avoid potential social sanctions. They may feel ashamed or

34. Posner (1997), above n. 23, at 367-69.

35. Posner and Rasmusen, above n. 12, at 370

36. Posner (1996), above n. 13, at 1736-1740.

37. Kraus, above n. 10, at 411

38. Cooter (1996), above n. 31, at 1642-1643. guilty when they smoke in public places. Others may also remind them to follow the new 'social' norm or even force them to stop smoking in public places with actions.

The internalisation process reflects a top-down approach to law-making. Through internalisation, a social foundation of newly established legal norms will be gradually developed in a community, which leads to an increase in the acceptance of and compliance with these internalised norms by community members. The cost of norm enforcement is thus reduced with the support of social sanctions. Furthermore, the internalisation process is also useful for harmonising different opinions of individuals. As shown in the smoking example previously, the promulgation of the new rule against smoking in public places influences the views of individuals on smoking and actually unifies originally opposite opinions. Thus, to some extent, the harmonisation effect of internalisation can help to reduce the disagreements between individuals, enable them to interact with each other more smoothly and thus reduce the unnecessary cost caused by disputes in social life.

\section{Social and Legal Norms in Transnational Commercial Transactions}

The interaction between social and legal norms not only exists at the national level but also occurs between the national and international dimensions. As discussed in the following sections, the rise of medieval lex mercatoria and its later incorporation into national laws in the early modern era is one example of the interaction between transnational commercial norms and national legal norms. The development of both social and legal norms in the field of transnational mercantile practice in past decades has significantly pluralised the regulatory framework for transnational commercial transactions. Various kinds of norms in this plural regime can be roughly categorised as national and international legal norms and uncodified and codified transnational commercial norms depending on whether the norms concerned are created and enforced by public or private mechanisms. $^{39}$

\subsection{Transnational Commercial Transactions: A Historical Perspective}

In medieval times, transnational commercial norms played an important role in the governance of transnational commercial transactions. Since the eleventh century, commercial activities have experienced a significant upsurge in Europe. The range of commercial transactions has rapidly expanded from inter-town business

39. As discussed in Section 3.4, it is difficult to draw a neat line of the norms in transnational commercial transactions. Thus, for the purpose of this article, they are roughly separated here on the basis of their creation and enforcement mechanisms. 
to cross-border trade. However, the development of cross-border commercial transactions has also brought problems to medieval merchants. Since merchants from different regions and countries normally had different trade usages and commercial customs, a set of unified exchange rules were needed to facilitate cross-border trade. ${ }^{40}$ These practical needs, as well as the cosmopolitan nature of transnational commercial transactions, helped medieval merchants to diminish the differences between mercantile practices. Through repeated transnational commercial transactions, transnational commercial norms were gradually generated, unified and accepted by medieval merchants in Europe, which constituted the basis of the medieval lex mercatoria.

It should be noted that these transnational commercial norms were not produced by state organs, but developed by the community of medieval merchants. ${ }^{41}$ The enforcement of these transnational commercial norms also relied mainly on the community of merchants. Medieval merchants established self-regulating institutions to enforce their commercial norms. With the support of these institutions, transnational commercial norms were 'voluntarily produced, voluntarily adjudicated and voluntarily enforced' by medieval merchants in Europe. ${ }^{42}$ Nonetheless, this did not necessarily mean that the medieval lex mercatoria, or, more precisely, transnational commercial norms at that time, were a complete set of norms that were sufficient for covering all the mercantile practice in medieval Europe. The usage of the medieval lex mercatoria could not be separated from local laws because of its insufficiency in providing detailed and precise legal guidance. ${ }^{43}$ More importantly, the development of the medieval lex mercatoria also relied on the revival of law as a scholarship and the emergence of trained legal specialists, which played an important role in the promotion of cross-border trade in medieval Europe. ${ }^{44}$

In the early modern era, the reinforcement of state power has led to a legal reform in Europe. ${ }^{45}$ National laws began to take over the role of the medieval lex mercatoria in the governance of transnational commercial transactions. Many states chose to selectively incorporate existing transnational commercial norms into their commercial codes. Examples were the Napoleon's Code de Commerce, the German Uniform Commercial Code and the Uniform Commercial Code in the United States. ${ }^{46}$ Although the medieval lex mercatoria had grad-

40. P.R. Milgrom, D.C. North \& B.R. Weingast, 'The Role of Institutions in the Revival of Trade: The Law Merchant, Private Judges, and the Champagne Fairs', 2 Economics and Politics 1, at 4-6 (1990).

41. N.E. Hatzimihail, 'The Many Lives-and Faces of Lex Mercatoria: History as Genealogy in International Business Law', 71 Law and Contemporary Problems 169, at 177 (2008).

42. Benson, above n. 10, at 647 .

43. C.W. Fassberg, 'Lex Mercatoria - Hoist with Its Own Petard?', 5 Chicago Journal of International Law 67, at 68 (2004).

44. H.-B. Schafer and A.J. Wulf, 'Jurists, Clerics, and Merchants: The Rise of Learned Law in Medieval Europe and Its Impact on Economic Growth', 11 Journal of Empirical Legal Studies 266, at 298-300 (2014).

45. Benson, above n. 10, at 651-52; J.H. Berman, Law and Revolution: The Formation of Western Legal Tradition (1983), at 341-42.

46. Michaels (2005), above n. 31, at 1232 ually come to an end in the codification movement, transnational commercial norms themselves did not vanish. Instead, particularly selected transnational commercial norms were refined through the codification efforts of states and persisted in a more systematic manner in national laws.

\subsection{National and International Legal Norms in Transnational Commercial Transactions}

In the codification movement, once unified transnational commercial norms were localised to adapt to the specific conditions of different countries. ${ }^{47}$ This change threw up a new question: which country's law should be applied in a cross-border transaction?

\subsubsection{National Legal Norms}

One traditional solution to this question is the private international law approach. Based on choice-of-law rules, the law of a specific country will be applied to govern a transnational commercial transaction. ${ }^{48}$ This approach, however, has several shortcomings. On the one hand, the usage of this approach may be costly, considering the potential time and cost for the parties to find and study foreign laws and the possible expenses for translations. ${ }^{49}$ The parties may also need to face unpredictable risk caused by unfamiliarity with foreign laws. ${ }^{50}$ On the other hand, this approach also cannot fully satisfy transnational merchants' needs for certainty and predictability. A transnational commercial contract may be signed, performed, modified or terminated in different countries. This transnational nature of crossborder transactions renders it difficult to ascertain the jurisdiction of courts and the applicable choice-of-law rules. As argued by Juenger, the 'methodological uncertainties' and 'inherent difficulties' of a private international law approach to cross-border mercantile practice inevitably lead to difficulties in guaranteeing certainty and predictability in transnational commercial transactions. ${ }^{51}$

To reduce unpredictability and uncertainty, the principle of party autonomy has been increasingly emphasised in modern theories of private international law and in the practice of transnational commercial transactions. ${ }^{52}$ Based on the principle of party autonomy, contracting parties can directly designate a specific country's law as the governing rules of their contracts so that the prob-

47. Fassberg, above n. 43 , at 72

48. Juenger, above n. 8 , at 1133

49. Maniruzzaman, above n. 1, at 658; Sweet, above n. 5, at 631

50. For example, when the parties select a third country's law that they are unfamiliar with, they may make incorrect predictions on the legal consequences of their actions, which may lead to unnecessary risk and cost in the processes of contract performance and dispute resolution. Petsche, above n. 11, at 464-66; P. Hachem and I. Schwenzer, 'The CISG Successes and Pitfalls', 57 The American Journal of Comparative Law 457, at 457-78 (2009).

51. Juenger, above n. 8 , at 1136-1140.

52. M. Zhang, 'Party Autonomy and Beyond: An International Perspective of Contractual Choice of Law', 20 Emory International Law Review 511, at 560-61 (2006); R. Engle, 'Party Autonomy in International Arbitration: Where Uniformity Gives Way to Predictability', 15 The Transnational Lawyer 323, at 334-40 (2002). 
lem of uncertainty and unpredictability can be tackled. However, the introduction of the party autonomy principle still cannot provide an effective solution to the potentially high cost of finding and studying foreign laws. ${ }^{53}$ Besides, national laws, which are essentially designed for domestic transactions, have been criticised to be ineffective for governing transnational commercial transactions. ${ }^{54}$ Domestic legislators generally pay more attention to domestic commercial practice and cannot always adequately respond to the specific needs of transnational merchants. ${ }^{55}$ Some domestic policies are also somewhat superfluous in the context of transnational commercial transactions. ${ }^{56}$

More importantly, national laws also cannot fully satisfy transnational merchants' needs of neutrality. Empirical statistics have shown that the parties prefer to select their home country laws with which they are more familiar. ${ }^{57}$ Accordingly, the parties may disagree on what law to choose, as each side wants to persuade the other to follow its own home country laws, which is quite common when the bargaining power between them is equal. As a result, an alternative choice that is more acceptable for both parties is to select a 'neutral law', a third country's law, for example. But, as mentioned, using a third country's law can be costly. Besides, even using a third country's law may still raise parties' concerns for neutrality, especially when trading parties come from different legal traditions. For example, which country's law is neutral for the parties from China and the United States in a Sino-US commercial transaction? British law can be an option considering its popular usage in international trade. ${ }^{58}$ But the Chinese side may still be reluctant to accept the suggestion of using British law, as the American side is probably more familiar with British law than the Chinese side.

\subsubsection{International Legal Norms}

A unified set of supranational legal norms can be an effective solution to the aforementioned deficiencies of national laws in the governance of transnational commercial transactions. However, the absence of a supranational government and required authority to impose

53. See above n. 49 and the accompanying text.

54. Petsche, above n. 11, at 458-75; Maniruzzaman, above n. 1, at 658

55. Petsche claimed that there are mainly three types of restrictions for transnational commercial transactions in domestic laws: 'restrictions on the parties' ability to address questions arising only in the international context, restrictions on the possibility for the parties to effectively respond to the needs of increasingly complex transactions, and restrictions based on legislative policies aimed at protecting weaker parties'. Petsche, above n. 11, at 471-76; Maniruzzaman, above n. 1, at 631

56. For example, an emphasis on the protection of weaker parties, such as consumers, is a reasonable policy in domestic context, while this policy is not that necessary for transitional merchants, which may lead to restrictions in transnational commercial transactions. Berger (2010), above n. 2, at 15-16; Petsche, above n. 11, at 474

57. There are a number of empirical surveys that show home country laws are normally the primary choices for transnational merchants. For a summary of these empirical findings, see Vogenauer, above n. 10, at 36-60.

58. British law is a popular choice for transnational merchants when they prefer a third country's national law as the governing law of their contracts. See below n. 88 and the accompanying text. cross-border legal sanctions renders it unrealistic to find a set of supranational legal norms that are truly compulsorily followed by all transnational merchants. Instead, international legal norms in international treaties that emerged in the last century have partly served the role of supranational legal norms. In a strict sense, these international legal norms are not directly legally binding as national legal norms. But, as will be shown in the discussion that follows, their potential in unifying national legal norms of different countries still merits attention.

This ambitious project of the unification of national laws was started by the International Institute for the Unification of Private law (UNIDROIT) in 1929. ${ }^{59}$ The general idea was to unify different national laws with an international legal framework consisting of multiple international treaties. ${ }^{60}$ Specifically, international treaties are binding on the states that have signed and ratified them, and member states are thus under the obligations to implement treaty provisions and introduce corresponding international legal norms into their national laws. As a result, if a set of international treaties regulating transnational commercial transactions can be ratified by enough countries, the international legal norms in these treaties will then become common rules for transnational commercial transactions over time. ${ }^{61}$

But this route of unifying national laws through international treaties is difficult to follow. It is not easy to build consensus between countries, considering their diverse legal traditions and economic development status. The initial attempt at unification in 1964 was relatively unsuccessful. Only a limited number of states ratified the Uniform Law on the International Sale of Goods (ULIS) and the Uniform Law on the Formation of Contracts for the International Sale of Goods (ULFC). ${ }^{62}$ Later, in 1968, the United Nations Commission on International Trade Law (UNCITRAL) started a new attempt and finally achieved a more encouraging result: the United Nations Convention on Contracts for the International Sale of Goods (CISG). This treaty has been signed by eighty-three states by now. ${ }^{63}$

The relative success of CISG, however, comes at a cost. The drafters of CISG had to not only study transnational mercantile practice and existing transnational commercial norms, but also strike a balance between different national legal provisions and diverging legislative emphases behind them. As a result, CISG excluded several important but controversial issues such as the validity of contracts (Art. 4) from its scope or used vague terms such as 'fundamental breach' and 'reasonable

59. K. Lipstein, 'One Hundred Years of Hague Conferences on Private International Law', 42 The International and Comparative Law Quarterly 553, at 554-57 (1993).

60. F. De Ly, 'Sources of International Sales Law: An Eclectic Model', 25 Journal of Law and Commerce 1, at 2 (2005).

61. Cremades and Plehn, above n. 6, at 321-22

62. For a detailed introduction to the history of the unification efforts, see M.J. Bonell, 'The UNIDROIT Principles of International Commercial Contracts and CISG - Alternatives or Complementary Instruments', 1 Uniform Law Review 26, at 27-28 (1996).

63. See_<www.uncitral.org/uncitral/en/uncitral_texts/sale_goods/1980 CISG_status.html> (last visited 1 June 2015). 
length' to regulate sensitive issues (Arts. 25, 47 and 63). The limited scope and vagueness of CISG provisions have been criticised by some scholars. ${ }^{64}$ To some extent, international treaties such as CISG have to be relatively vague and leave necessary room for national laws so that they can be more influential among states and more widely accepted by them. De Ly defines this compromising approach as an 'eclectic model' that combines both international treaty provisions and national laws for the governance of transnational commercial transactions. ${ }^{65}$

In general, although CISG is an important step towards the unification of national laws, it is still far away from a uniform international code for transnational commercial transactions. The stateless nature of CISG-like international treaties can respond to transnational merchants' needs for neutrality. But, as discussed in the previous paragraphs, international legal norms at the current stage still face difficulties in providing sufficient and detailed guidance for merchants in transnational commercial transactions because of their relative vagueness and restricted scope.

\subsection{Transnational Commercial Norms}

Given that national and international legal norms, to some extent, cannot provide a fully satisfactory answer for the governance of transnational commercial transactions, transnational commercial norms, as a set of supranational social norms generated from transnational mercantile practice, have drawn the attention of both scholars and practitioners. ${ }^{66}$ These norms can be roughly categorised as uncodified and codified transnational commercial norms. ${ }^{67}$

\subsubsection{Uncodified Transnational Commercial Norms: Commercial Customs and Trade Usages}

Some transnational commercial norms are unwritten or at least uncodified. They can be roughly named in a collective manner as commercial customs and trade usages that are distilled from repeated transnational commercial transactions and voluntarily followed by transnational merchants even when they are not explicitly specified in contracts. ${ }^{68}$ The scope of commercial norms and trade usages is quite broad and can be rather general. Examples are the principles of pacta sunt servanda and good faith. They can also be relatively specific. For example, contracting parties may not set a specific time limit for the examination of bank documents in their contracts, but they may still have a sense of reasonable time limit in their minds. ${ }^{69}$ Although these examples can be useful for understanding uncodified commercial norms, it still seems difficult to precisely describe what they are. As argued by Lord Musttill, commercial customs and trade usages are 'simply a practice which is generally followed', and some principles are 'so general as to be useless' ${ }^{70}$

Commercial customs and trade usages are frequently reflected in standardised contractual terms and published arbitration awards. In repeated commercial transactions, certain contractual terms, such as the way of transportation or the method of payment, are repeated without significant changes in different contracts. Over time, these contractual terms then gradually become standardised, and the parties do not need to spend time to negotiate the details of these standardised contractual terms. Accordingly, these standardised contractual terms then form one particular type of commercial customs and trade usages. ${ }^{71}$ It is common to find that contracting parties simply follow these standardised contractual terms so that they can focus more on the negotiation of other contractual clauses such as price, quantity and quality that are more important for them. ${ }^{72}$

Published arbitration awards can also signal the recognition of commercial customs and trade usages. It is possible that a disputable issue is not specified in the contract and the applicable law also does not provide enough guidance for arbitrators to decide the disputable issue. Empirical studies show that many arbitrators are consciously using their understanding of commercial customs and trade usages to fill the aforementioned gap in law when rendering arbitration awards. ${ }^{73}$ When similar opinions are repeatedly found in published arbitration awards on the disputable issue, a rough consensus could then develop on the basis of these published arbitration awards, which may gradually turn into commercial customs and trade usages when enough merchants and arbitrators accept it. ${ }^{74}$ But it should be noted that in deference to the traditional value of confidentiality in international commercial arbitration, most arbitration awards are not published. Accordingly, the crystallisation of uncodified transnational commercial norms based on
64. See e.g. Smits, 'Problems of Uniform Sales Law - Why the CISG may not Promote International Trade', Maastricht European Private Law Institute Working Paper 2013:1, at 6-9. There are also voices against the criticism levelled at the CISG. See e.g. Hachem and Schwenzer, above n. 50, at 467-78

65. De Ly (2005), above n. 60, at 3. Besides, there is also empirical evidence suggesting that CISG is not frequently referred to in transnational commercial transactions. See below n. 96 and the accompanying text.

66. This is evident in the literature on modern lex mercatoria, see above $\mathrm{n}$. 2.

67. For a general introduction to the sources of transnational commercial norms, see Maniruzzaman, above n. 1, at 672-73. See also O. Lando, 'The Lex Mercatoria in International Commercial Arbitration', 34 International and Comparative Law Quarterly 747, at 747-68 (1985).

68. R. Goode, 'Usage and Its Reception in Transnational Commercial Law', 46 International and Comparative Law Quarterly 1, at 7 (1997).
69. Ibid., at 12

70. Musttill, above n. 2, at 92-94.

71. For example, if email is stated as a formal mean of notification in most transnational commercial contracts, email will then naturally become one of the formal communication methods in transnational commercial transactions over time. Cremades and Plehn, above n. 6, at 347. See also C.M. Schmitthoff, 'The Unification or Harmonisation of Law by Means of Standard Contracts and General Conditions', 17 International and Comparative Law Quarterly 551, at 551-57 (1968).

72. Musttill, above n. 2, at 95; Berger (2010), above n. 2, at 284-86.

73. Cremades and Plehn, above n. 6, at 335-46.

74. Maniruzzaman, above n. 1, at 693-94. 
published arbitration awards is somewhat restricted in practice. $^{75}$

\subsubsection{Codified Transnational Commercial Norms: Trade Standards, Private Codification and Model Lams}

Similarly to legislators at the national level, many international institutions function as the codifiers of transnational commercial norms at the international level. Serving different purposes, transnational commercial norms are codified in different kinds of regulatory documents. These codified transnational commercial norms are not legally binding in a strict sense, but are subject to the voluntary compliance of transnational merchants in principle. Depending on the nature of the international institutions, there are mainly three kinds of codified transnational commercial norms, namely trade standards, private codification and model laws.

Some international institutions, such as the International Chamber of Commerce (ICC), the International Accounting Standards Board (IASB) and the International Organisation for Standardisation (ISO), generalise mercantile practice and issue unified trade standards for transnational merchants. ${ }^{76}$ One influential example of technical standards is the Incoterms (International Commercial Terms) issued by ICC. ${ }^{77}$ Similarly to standardised contractual terms, these technical standards can save merchants' time and energy in contract negotiation. Moreover, as shown in the coordination game model, following unified standards can also avoid unnecessary costs. For example, using the same commercial terms can reduce the chances of misunderstandings and accompanying losses caused by misunderstandings. Besides, there are also many trade associations that issue more specific trade association standards for association members in particular industries. It is noteworthy that association members normally have a strong incentive to follow trade association standards. As shown in the repeated games model, association members are generally willing to maintain their reputation in trade associations for securing further opportunities of commercial transactions. Violating trade association standards will damage their reputation in the association and reduce other association members' desire to trade with them. Even without substantial sanctions, the

75. For related discussion, see e.g. A. Schmitz, 'Untangling the Privacy Paradox in Arbitration', 54 Kansas Law Review 1211, at 1211-1253 (2006); C.G. Buys, 'The Tensions Between Confidentiality and Transparency in International Arbitration', 14 The American Review of International Arbitration 121, at 121-38 (2003).

76. For a detailed study on international institutions that are dedicated to the codification of uncodified transnational commercial norms, see J.K. Levit, 'A Bottom-Up Approach to International Lawmaking: The Tale of Three Trade Finance Instruments', 30 The Yale Journal of International Law 125 (2005).

77. Incoterms provides a set of unified terms for transnational merchants to more clearly and easily describe their rights and duties in contracts. For an official introduction, available at: <www.iccwbo.org/products-andservices/trade-facilitation/incoterms-2010/the-incoterms-rules/> (last visited 20 December 2015). potential losses of trade opportunities are already severe punishment for those who conduct deviant behaviour. ${ }^{78}$ Other international institutions are more dedicated to the codification of commercial customs and trade usages. The UNIDROIT Principles are regarded as a typical kind of private codification of transnational commercial norms. ${ }^{79}$ The drafting process of the UNIDROIT Principles is quite similar to CISG. A group of renowned experts organised by UNIDROIT study transnational commercial norms and codify them into the UNIDROIT Principles. But, instead of pursuing legally binding power from states' recognition, the UNIDROIT Principles exerts their influence through their persuasive power and the authority of their issuing organisation, the approach of which is quite similar to the restatements of laws in the United States. ${ }^{80}$ The UNIDROIT Principles inform judges, arbitrators, lawyers and merchants about the current transnational mercantile practice and provide them with codified transnational commercial norms that can be readily used. ${ }^{81}$ The UNIDROIT Principles can be directly designated by contracting parties as the governing rules for their contracts, provided that the application of the UNIDROIT Principles does not violate the mandatory rules in corresponding national laws. The UNIDROIT Principles can also serve as the interpretative or supplementary reference for national and international legal norms. ${ }^{82}$

Another noteworthy codifier at the international level is UNCITRAL. Apart from the aforementioned function of producing international legal norms in international treaties such as CISG, UNCITRAL also plays an active role in codifying transnational commercial norms through model laws. But, slightly different from UNIDROIT, UNCITRAL, as a subordinate of the United Nations, primarily serves for states. Its model laws provide suggested provisions as reference for national legislators. Different from international treaties, states are under no treaty obligations and are free to decide whether to follow the provisions in model laws. Thus, in a strict sense, the provisions in model laws are also not binding legal norms in the first place, though they have the potential to be legally binding if they are adopted by national laws. UNCITRAL's model laws cover various

78. B. Klein and K.B. Leffler, 'The Role of Market Forces in Assuring Contractual Performance', 89 Journal of Political Economy 615, at 633-37 (1981).

79. Calliess, above n. 8 , at 474.

80. F. De Ly, 'Lex Mercatoria (New Law Merchant): Globalisation and International Self-Regulation', in R.P. Appelbaum, W.L.F. Felstiner and V. Gessner (eds.), Rules and Networks: The Legal Culture of Global Business Transactions (2001) 159, at 165

81. G. Baron, 'Do the UNIDROIT Principles of International Commercial Contracts Form a New Lex Mercatoria', 15 Arbitration International 115 , at 130 (1999).

82. R. Michaels, 'Preamble I: Purposes, Legal Nature, and Scope of the PICC; Applicability by Courts; Use of the PICC for the Purpose of Interpretation and Supplementation and as a Model', in S. Vogenauer and Kleinheisterkamp (eds.), Commentary on the UNIDROIT Principles of International Commercial Contracts (2009) 21, at 25-29; A.M. Garro, 'The Gap-Filling Role of the UNIDROIT Principles in International Sales Law: Some Comments on the Interplay between the Principles and the CISG', 69 Tulane Law Review 1149, at 1149-1150 (1995). 
commercial fields, including international commercial arbitration, insolvency, international payment, electronic commerce and public procurement, which generally receive positive comments from scholars. ${ }^{83}$ The UNCITRAL Model Law on International Commercial Arbitration is one particularly successful example that has been adopted by sixty-seven countries by now. ${ }^{84}$ With the increasing number of states that are adopting the Model Law on International Commercial Arbitration, the norms in this model law will be gradually accepted as the universal rules for regulating international commercial arbitration. ${ }^{85}$ However, it should be noted that it is still unclear whether the success of the model law approach in the field of international commercial arbitration implies that this approach would be successful in other fields too. Until now, UNCITRAL's model laws on other commercial issues have been adopted only by a limited number of countries. ${ }^{86}$

\subsection{Continuum between Legal and}

Transnational Commercial Norms

From the emergence of the medieval lex mercatoria up to today's hybrid regimes for the governance of transnational commercial transactions, both legal norms, be they national or international, and social norms, be they codified and uncodified, have constantly evolved in light of the ever-changing needs of transnational merchants. It can be found from the previous discussion that norms in transitional commercial transactions, from a general perspective, follow a continuum. From uncodified and codified transnational commercial norms to international and national legal norms, the norms on the continuum become increasingly precise, systematic, authoritative and coercive.

In the middle of the continuum, the close connection and constant interaction between different kinds of norms render it difficult to draw a neat line between

83. For related literature, see e.g. S. Arrowsmith, 'Public Procurement: An Appraisal of the UNCITRAL Model Law as a Global Standard', 53 British Journal of International and Comparative Law 17 (2004); J. Clift, 'The UNCITRAL Model Law on Cross-Border Insolvency-A Legislative Framework to Facilitate Coordination and Cooperation in Cross-Border Insolvency', 12 Tulane Journal of International and Comparative Law 307 (2004); A.J. Berends, 'The UNCITRAL Model Law on Cross-Border Insolvency: A Comprehensive Overview', 6 Tulane Journal of International and Comparative Law 309 (1998); A.B. Overby, 'Will Cyberlaw Be Uniform? An Introduction to the UNCITRAL Model Law on Electronic Commerce', 7 Tulane Journal of International and Comparative Law 219 (1999).

84. See <www.uncitral.org/uncitral/en/uncitral_texts/arbitration/1985 Model_arbitration_status.html> (last visited 1 June 2015).

85. M.F. Hoeellering, 'The UNCITRAL Model Law on International Commercial Arbitration', 20 The International Lawyer 327, at 339 (1986).

86. For example, the UNCITRAL Model Law on Cross-Border Insolvency is adopted by only twenty-two countries, available at: <www.uncitral.org/ uncitral/en/uncitral_texts/insolvency/1997Model_status.html> (last visited 1 June 2015); the UNCITRAL Model Law on Electronic Signatures (2001) is adopted by only thirty-one countries, available at: <www. uncitral.org/uncitral/en/uncitral_texts/electronic_commerce/ 2001Model_status.html> (last visited 1 June 2015); the UNCITRAL Model Law on Public Procurement (2011) is only referred as the legal reform guideline in fourteen countries, available at: <www.uncitral.org/ uncitral/en/uncitral_texts/procurement_infrastructure/2011Model_ status.html> (last visited 1 June 2015). them. To some extent, the norms in the middle areas share the features of both social and legal norms. For example, the provisions in the UNIDROIT Principles are privately produced and not legally binding. But they can be directly designated as the governing rules of transnational commercial transactions and become legally binding for contracting parties. Similarly, UNCITRAL's model laws are also not directly binding from a legal perspective. But the norms in model laws can indirectly become legally binding when they are absorbed into national laws.

From this perspective, norms in trade standards, private codification and model laws and even international treaties in a broader sense fall into the same category. They are the products of the codification efforts of international institutions. In a strict sense, these codified transnational commercial norms are not legally binding, but they can be rather influential among practitioners and voluntarily followed by them.

Having reviewed the main sources of social and legal norms in today's transnational commercial transactions, the following sections go on to study how these norms interact with each other through incorporation and internalisation, what is the role of uncodified transnational commercial norms in this interaction and what are the challenges that put pressure on this interaction.

\section{Incorporation and Internalisation in Transnational Mercantile Practice}

\subsection{Incorporation and Internalisation between National and International Dimensions}

Today's national laws still selectively incorporate transnational commercial norms. As noted by Fassberg, transnational commercial norms in both uncodified and codified forms are still important sources for national laws. ${ }^{87}$ In essence, today's interaction between commercial norms at the international level and legal norms at the national level is generally the same as it was in the codification movement in the early modern era. National laws can more adequately respond to the specific needs of mercantile practice and become more attractive to merchants by incorporating transnational commercial norms.

Compared with incorporation, internalisation seems to be less visible between national legal norms and transnational commercial norms. It seems inappropriate to argue that legal norms in national laws have little impact on parties' opinions in commercial activities. If a national law such as English Law or Swiss Law in Europe is frequently selected by contracting parties in cross-border commercial transactions, internalisation will inevita-

87. Fassberg, above n. 43 , at 72 . 
bly happen as a result of transnational merchants' repeated compliance. ${ }^{88}$ For example, imagine that all transnational merchants select one particular national regime to govern the contractual relations between the parties. Naturally, legal norms in this national regime would become universal rules at the international level and be gradually internalised by transnational merchants just as they are at the national level. However, in reality, there still seems to be no specific national legal regime that takes a dominating position in the governance of transnational commercial transactions.

\subsection{Incorporation and Internalisation within the} International Dimension

A more interesting type of interaction occurs within the international dimension between codified and uncodified transnational commercial norms. Because of the absence of a supranational government, it is unrealistic to find a legislative body at the international level that has the authority to produce and enforce supranational legal norms that should compulsorily be followed by all transnational merchants. But codified transnational commercial norms can, to some extent, function as substitutes for supranational legal norms. Although international institutions cannot directly transform uncodified transnational commercial norms into binding supranational legal norms that have the jurisdictional power as national legal norms, they can still study, refine and incorporate uncodified transnational commercial norms into codified transnational commercial norms. ${ }^{89}$

The incorporation of uncodified transnational commercial norms into codified transnational commercial norms produces a similar systematisation effect as the incorporation of social norms at the national level. Transitional merchants may have difficulties in finding fragmented uncodified transnational commercial norms without the help of specialists such as lawyers and scholars. They may also get confused about how to correctly use uncodified transnational commercial norms, as these norms are normally general, vague and imprecise. However, through the efforts of international institutions, once unwritten, fragmented and vague transnational commercial norms can turn into written, coherent and precise codified transnational commercial norms. ${ }^{90}$ These codified transnational commercial norms can be easily found on the Internet with multiple language translations. They are also accompanied by comments or explanatory notes to instruct users on how to interpret

88. Empirical evidence shows that English law and Swiss law enjoy considerable popularity in cross-border commercial transaction in Europe. For a summary, see H. Eidenmuller, 'Regulatory Competition in Contract Law and Dispute Resolution', in H. Eidenmuller (ed.), Regulatory Competition in Contract Law and Dispute Resolution (2013) 1, at 2. For full results of the survey, see Institute of European and Comparative Law, University of Oxford Faculty of Law, Oxford Civil Justice Survey, available at: <www3.law.ox.ac.uk/themes/iecl/ocjsurvey.shtml> (last visited on 20 November 2015)

89. Levit, above n. 76, at 190-91.

90. Baron, above n. 81, at 130 . the provisions. ${ }^{91}$ As a result, transnational merchants could be less worried about where to find and how to use these norms. They can simply select and use codified transnational commercial norms prepared by international institutions when necessary. This development largely reduces the cost for transnational merchants of using transnational commercial norms.

The importance of internalisation at the international level is reflected mainly in its harmonisation effect. Influenced by different legal traditions and mercantile practices, merchants from different countries and jurisdictions may disagree over the interpretation of certain contractual terms, which may escalate into disputes if these disagreements are not settled properly. As noticed by many scholars, these disputes can be avoided through the harmonisation effect of internalisation, though this theoretical possibility has not been adequately tested by empirical studies. ${ }^{92}$ Newly established legal norms can be gradually internalised by individuals and function as social norms in a community. ${ }^{93}$ This harmonisation effect is also evident at the international level. When transnational merchants repeatedly follow certain codified transnational commercial norms, ${ }^{94}$ they will gradually accept these provisions as the common reference for interpreting contractual terms. Moreover, through internalisation, transnational merchants may also gradually accept these unified transnational commercial norms instead of insisting on their own countries' commercial customs and trade usages. By constantly following codified transnational commercial norms, transnational merchants' different opinions derived from country-specific conditions can be gradually harmonised. ${ }^{95}$ As a consequence, this harmonisation effect can provide transnational merchants with a common language in mercantile practice and thereby reduce the possibility of disputes fuelled by diverging domestic approaches to transnational commercial trade.

91. For example, the main texts of UNIDROIT Principles (2010) and the UNCITRAL Model Law on International Commercial Arbitration (1985) are all accompanied by explanatory notes.

92. For the literature discussing the harmonisation effect from a theoretical perspective, see e.g. Gomez, above n. 10, at 89-118; Wagner, above n. 10, at 77-87; P.B. Stephan, 'The Futility of Unification and Harmonization in International Commercial Law', 39 Virginia Journal of International Law 743, at 743-98 (1999). See also related discussion in Section 2.2.

93. Ibid

94. Soft codes, such as CISG and the UNIDROIT Principles, have already been listed as recommending governing rules for transnational commercial transactions in model contracts of international organisations. See e.g. Art. 5 (Applicable law and guiding principles), Model Contracts for Small Firms: International Commercial Sale of Goods, International Trade Centre (2010), available at: <www.intracen.org/WorkArea/ DownloadAsset.aspx?id=37603> (last visited 1 May 2016).

95. This kind of bottom-up harmonisation can complement the top-down harmonisation through international and national legislation. To some extent, the bottom-up harmonisation can be more effective than the top-down approach, as it directly affects transnational merchants, the users of norms, rather than seeking a compromise between different countries in international treaties and affecting transnational merchants indirectly via the connections between national and international laws. 
4.3 Practical Challenges to the Development of Codified Transnational Commercial Norms and to the Incorporation and Internalisation Processes

Theoretically speaking, the previous discussion indicates that codified transnational commercial norms can be useful in the governance of transnational commercial transactions. Apart from the aforementioned merits of reducing cost and preventing disputes brought by the systematisation and harmonisation effects, codified transnational commercial norms are also attractive to transnational merchants with regard to neutrality and commercial sensitivity. Since codified transnational commercial norms are not tied to state authority, the neutrality of these norms with regard to 'nationality' can be guaranteed. ${ }^{96}$ Besides, codified transnational commercial norms, following a bottom-up approach, are essentially generated by transnational merchants themselves on the basis of their own mercantile practice and can thus break the limits of national boundaries and directly respond to the specific needs of transnational merchants in international trade. ${ }^{97}$

The reliance on codified transnational commercial norms in reality, however, seems to be less considerable than expected. Empirical studies show that the usage of codified transnational commercial norms, compared with national legal norms, is rather limited in transnational commercial transactions. ${ }^{98}$ In a more recent Queen Mary's international arbitration survey, around half of respondents claim that they have, at least 'sometimes', used 'transnational laws and rules'. 99 But the survey also suggests that codified transnational commercial norms are normally used as a supplement to national laws for interpretation and definition purposes. They are seldom used independently as the main rules for governing transnational commercial transactions. ${ }^{100}$ There are also a number of empirical surveys showing similar results directly or indirectly. ${ }^{101}$

There are several reasons why the theoretical prospect of codified transnational commercial norms seems to be less promising in practice. First, transnational merchants are still relatively unfamiliar with codified transnational commercial norms. Unlike national legal

96. Transnational merchants' particular needs of neutrality in the governing laws of contracts is evident in empirical surveys; see e.g. Queen Mary University of London, 2010 International Arbitration Survey: Choices in International Arbitration, at 11, available at: <www.arbitration.qmul.ac. uk/research/2010/index.html> (last visited on 20 November 2015)

97. For example, long-distance transportation is quite common in transnational commercial transactions, but less frequent in domestic transactions. Accordingly, related issues regarding long-distance transportation may be inadequately regulated in national laws, but more effectively governed by transnational commercial norms. Sweet, above n. 5, at 632.

98. C.R. Drahozal, 'Contracting out of National Law: An Empirical Look at the New Law Merchant', 80 Notre Dame Law Review 523, at 537-46 (2005).

99. See above n. 96 , at 15 .

100. Ibid

101. See e.g. Cunieberti, above n. 11, at 396-404. For a useful summary and comment on related empirical findings, see Vogenauer, above n. 10, at 36-60. norms, codified transnational commercial norms lack jurisdictional coercion. ${ }^{102}$ In domestic commercial transactions, merchants are subject to the jurisdiction of national laws and are forced to follow national legal norms. The compulsory nature of national legal norms significantly increases the possibility of internalisation of these legal norms. However, international organisations generally lack the coercive power to force transnational merchants to follow codified transnational commercial norms issued by them. Second, compared with national legal norms that have been developed for centuries, modern codified transnational commercial norms are still quite 'young'. Their relatively short history cannot provide them with sufficient time to perfect themselves. The relatively limited usage of codified transnational commercial norms in practice also renders it difficult for them to be substantially tested in transnational commercial transactions. To some extent, these obstacles also lead to the relative immaturity of codified transnational commercial norms, which in turn reduces transnational merchants' incentives to use them. Third, there might be a principal-agent problem. Lawyers may prefer to advise clients to choose certain national laws in which they are specialised, though the suggested choices of national laws do not necessarily best serve the interests of their clients. ${ }^{103}$

More importantly, all these practical obstacles not only lead to the relative unpopularity of codified transnational commercial norms but also hinder the interaction between codified and uncodified transnational commercial norms. Because of transnational merchants' unfamiliarity with codified transnational commercial norms and their reluctance to use them, the internalisation process will be inevitably prolonged. ${ }^{104}$ Meanwhile, the limited usage of codified transnational commercial norms cannot effectively increase the influence of international institutions among transnational merchants. Accordingly, benefiting little from producing codified transnational commercial norms, international organisations may have fewer incentives to continually dedicate themselves to incorporating uncodified transnational commercial norms. In general, the impediment to incorporation and internalisation may negatively affect the systematisation and harmonisation effects and eventually hinder further development of codified transnational commercial norms.

\section{Conclusion}

From a law and economics perspective, this article approaches the norms in transnational commercial

102. Smits, above n. 64, at 9-10.

103. See Hachem and Schwenzer, above n. 50, at 464. But, of course, the principal-agent problem can also occur in another direction. Lawyers who are knowledgeable about transnational commercial norms may also try to persuade their clients to choose them, though such suggestions also may not be the best for their clients. See Cunieberti, above $\mathrm{n}$. 11 , at 406-21.

104. Cunieberti, above n. 11, at 384-96. 
transactions by studying the interaction between these norms and the effects of the interaction on them. Rooted in private or public mechanisms, the creation and enforcement of social and legal norms follow different patterns that provide them with different strengths and drawbacks. But these differences can also be diminished by the interaction between them. This interaction blurs the boundaries between social and legal norms, bridges the gaps between them and creates a common basis for them to complement each other so that they can become more efficient tools (in the sense of cost reduction) for guiding individuals' behaviour and maintaining social order.

At the national level, the incorporation of social norms and internalisation of legal norms can systematise social norms, harmonise disagreements and enhance individuals' compliance with social and legal norms. Incorporated social norms and internalised legal norms become more systematic, unified and coercive so that individuals can better recognise, accept and follow them. Accordingly, the cost of following and enforcing these norms is reduced as a result of the systematisation and compliance enhancement effects, while the harmonisation effect can gradually unify individuals' different opinions on controversial issues, prevent disputes caused by these disagreements and thus avoid the unnecessary cost incurred from these disputes.

The incorporation and internationalisation processes at the international level tell a similar yet different story. The systematisation and harmonisation effects still play an important role in reducing the usage cost of transnational commercial norms and reducing disagreements between merchants from different countries. To some extent, these two effects are more important and evident at the international level than at the national level. Originally fragmented, imprecise and unwritten uncodified transnational commercial norms are relatively difficult for transnational merchants to use and follow. The systematisation effect of incorporation thus becomes crucial for the spread and usage of transnational commercial norms. Similarly, merchants from different countries may hold opinions that are more divergent than those from one country. The harmonisation effect of internalisation can thus play a part in unifying transnational merchants' views on contractual terms, reducing the collision between them and avoiding the unnecessary cost generated from disputes.

But, different from the national level, the effect of compliance enhancement is less visible at the international level. The absence of a supranational government leads to difficulties in establishing supranational legal norms. Lacking the jurisdictional power of state organs at the national level, international organisations cannot force transnational merchants to follow codified transnational commercial norms issued by them. On a voluntary basis, whether these norms can be followed in practice depends largely on the familiarity of transnational merchants with them. But empirical evidence seems to suggest that the development of codified transnational commercial norms and the interaction between codified and uncodified transnational commercial norms is more or less hindered by practical obstacles.

Currently, codified transnational commercial norms are still far from being a mature and complete body of rules for the governance of transnational commercial transactions. But the growing importance of these norms in this field should not be ignored. Codified transnational commercial norms are being recognised and followed by more and more transnational merchants in practice. The increasing usage of codified transnational commercial norms is slowly but steadily forming a basis for their further development. Accordingly, the harmonisation, systematisation and even compliance enhancement effects derived from the incorporation and internalisation processes can be expected in the long run.

It should be noted, however, that the findings of this article are mainly theoretical reflections on the interaction between norms in transnational commercial transactions. Further studies, empirical ones in particular, are needed to more accurately describe this interaction and predict the role of codified transnational commercial norms in the governance of transnational commercial transactions. Although it is still too early to tell which kinds of norms will take a dominating position in this field, it can be expected that transnational commercial norms, codified ones in particular, will continue to complement and compete with national legal norms and play an increasingly important role in the governance of transnational commercial transactions. 